\title{
SWOC Analysis and strategies for Promotion of Organic Paddy Farming in Cauvery Delta Zone of Tamil Nadu, India
}

\author{
D. Karpagam ${ }^{1} *$ and R. Jansirani ${ }^{2}$ \\ ${ }^{1}$ Department of Agricultural Extension and Rural Sociology, ${ }^{2}$ Department of Sustainable \\ Organic Agriculture, Tamil Nadu Agricultural University, Coimbatore-641003, India
}

*Corresponding author

\begin{tabular}{l} 
Ke y w o r d s \\
SWOC, \\
Organic paddy \\
farming, \\
Cauvery delta zone, \\
Opportunities and \\
Challenges \\
\hline Article Info \\
\hline $\begin{array}{l}\text { Accepted: } \\
\text { 04 April } 2019 \\
\text { Available Online: } \\
\text { 10 May } 2019\end{array}$ \\
\hline
\end{tabular}

\section{A B S T R A C T}

SWOC analysis is a strategic planning method used to research external and internal factors which affect company success and growth. Firms use SWOC analysis to determine the Strengths, Weaknesses, Opportunities and Challenges of the firm, products and competition. A study was conducted to investigate the prospects of organic paddy farming in Cauvery Delta Zone of Tamil Nadu for SWOC analysis on organic paddy farming. 180 organic paddy farmers were selected by proportionate random sampling technique. Majority of the organic paddy framers perceived and ranked low cost of production (I rank), sustainability (II rank) and use of indigenous technologies (III rank) were strengths. Weaknesses include inadequate technology, lower yield and less awareness were first, second and third rank respectively. Opportunities perceived by majority of organic paddy farmers were growing environmental concern (I rank), growing health awareness (II rank) and increasing market demand (III rank). Costly and complex organic certification process (I rank), weed problems (II rank) and most of the fields are contiguous and problem of contamination (III rank) were the challenges as perceived by organic paddy farmers. Based on the result of SWOC, strategies were suggested for the development of organic paddy farming in research extension, production, processing and marketing sectors.

\section{Introduction}

SWOC (Strength, Weakness, Opportunities and Challenges) analysis is a process that identifies an organization's strengths, weaknesses, opportunities and Challenges. It is a basic analytical framework that assesses what an entity (usually a business, farm, industry or product) can and cannot do, for factors both internal (Strengths and Weaknesses) as well as external
(Opportunities, and Challenges) Rao (2016). A SWOC analysis was employed for identifying the strengths, weaknesses, opportunities, and Challenges as perceived by the organic paddy farmers involved in Organic Faddy Farming in Cauvery Delta Zone of Tamil Nadu. This analysis is expected to highlight the points for an in depth understanding of the situation in its totality, which in turn helps the top administrators, planners of state government, 
scientists to take strategic decision to overcome the weaknesses and challenges in organic paddy farming. Strengths were categorized as internal helpful factors and weaknesses as internal hindering factors of organic paddy farming. Opportunities were external helpful factors and Challenges the external harmful factors.

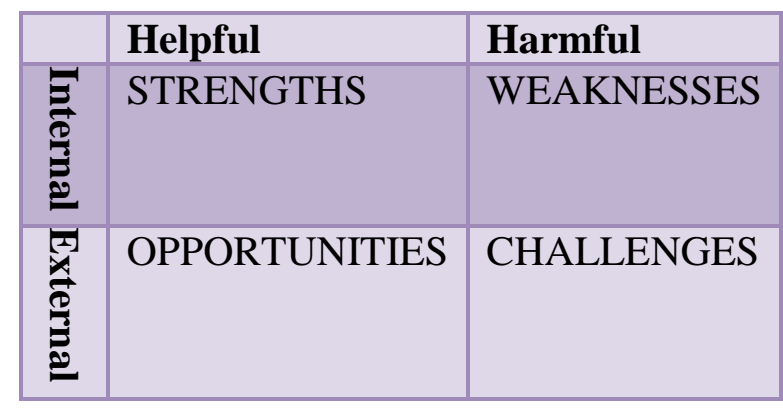

\section{Materials and Methods}

This study was conducted in Cauvery Delta Zone (CDZ) of Tamil Nadu for considering the maximum area under Paddy cultivation. Thanjavur, Thiruvarur and Tiruchirappalli Districts were selected purposively, due to the maximum number of certified organic paddy farmers. For studying the strengths, weaknesses, opportunities and challenges, 180 organic paddy farmers were selected by proportionate random sampling technique. A schedule was prepared to unearth the SWOC of organic paddy farming. the perceived responses of the farmers under each parameter were listed.

Nine important strengths, weaknesses, opportunities and challenges (Fig. 1) were identified by applying Rank Based Quotient (RBQ) developed by Sabaratnam (1998). The data obtained from the organic paddy farmers regarding strengths, weaknesses, opportunities and challenges parameters in organic paddy farming was quantified i.e. the number of organic paddy farmers who gave the particular rank were used for calculation of RBQ.
The formula for RBQ calculation is as follows

$$
R B Q=\frac{(f i)(n+1-i) \times 100}{N n}
$$

Where,

fi - Frequency of organic paddy farmers for $i^{\text {th }}$ rank of SWOC parameters

$\mathrm{N}$ - Number of organic paddy farmers

$\mathrm{n}$ - Number of ranks

\section{Results and Discussion}

\section{SWOC analysis on organic paddy farming}

In order to understand the nature of the Strengths, weaknesses, Opportunities and Challenges of organic paddy farming as perceived by the organic paddy farmers, rank based quotients were computed and the values had been presented in Table 1 to 4 .

The strategy was designed with the following interventions based on SWOC analysis for efficient production of organic paddy farming in Cauvery Delta Zone of Tamil Nadu.

\section{Strategies for promotion of organic paddy farming}

\section{Research intervention}

The following intervention on research to be needed for promotion of organic paddy farming.

- Documentation and validation of indigenous technologies

- Conserve traditional paddy varieties

- Take up research on organic paddy farming for its promotion

- Quality control of organic inputs

- Tested the organic inputs in trial basis for large scale adoption. 
Table.1 Strengths of Organic paddy farming perceived by organic paddy farmers

\begin{tabular}{|c|c|c|c|c|c|c|c|c|c|c|c|c|}
\hline \multirow{2}{*}{$\begin{array}{c}\text { S. } \\
\text { No. }\end{array}$} & \multirow[t]{2}{*}{ Strength } & \multicolumn{11}{|c|}{ Ranks } \\
\hline & & I & II & III & IV & $\mathbf{V}$ & VI & VII & VIII & IX & RBQ & Rank \\
\hline 1 & Sustainability & 33 & 38 & 38 & 36 & 35 & & & & & 77.655 & II \\
\hline 2 & Quality Product & 23 & 27 & 30 & 33 & 36 & 31 & & & & 70.062 & V \\
\hline 3 & High social value & & & & & 46 & 38 & 23 & 45 & 28 & 32.407 & VII \\
\hline 4 & $\begin{array}{l}\text { Low cost of } \\
\text { production }\end{array}$ & 40 & 42 & 59 & 12 & & 10 & 17 & & & 80.618 & I \\
\hline 5 & Improve soil health & 41 & 41 & 33 & 19 & 20 & & & 26 & & 70.494 & IV \\
\hline 6 & $\begin{array}{l}\text { Preserves traditional } \\
\text { paddy varieties with } \\
\text { high medicinal } \\
\text { values }\end{array}$ & & & & & 13 & 37 & 43 & 35 & 52 & 29.629 & IX \\
\hline 7 & $\begin{array}{l}\text { Use of indigenous } \\
\text { technologies }\end{array}$ & 43 & 32 & 20 & 40 & & & 45 & & & 77.037 & III \\
\hline 8 & $\begin{array}{l}\text { Production inputs are } \\
\text { chiefly available }\end{array}$ & & & & 12 & 12 & 35 & 34 & 38 & 49 & 35.494 & VI \\
\hline 9 & $\begin{array}{l}\text { Huge demand by } \\
\text { customers }\end{array}$ & & & & 28 & 18 & 29 & 18 & 36 & 51 & 31.790 & VIII \\
\hline
\end{tabular}

Majority of the organic paddy framers perceived low cost of production (I rank) sustainability (II rank) and use of indigenous technologies (III rank) were strengths

Table.2 Weaknesses of organic paddy farming perceived by organic paddy farmers

\begin{tabular}{|c|c|c|c|c|c|c|c|c|c|c|c|c|}
\hline \multirow{2}{*}{$\begin{array}{c}\text { S. } \\
\text { No. }\end{array}$} & \multirow[t]{2}{*}{ Weakness } & \multicolumn{11}{|c|}{ Ranks } \\
\hline & & I & II & III & IV & $\mathbf{v}$ & VI & V II & VIII & IX & RBQ & Rank \\
\hline 1 & $\begin{array}{l}\text { Inadequate } \\
\text { technology }\end{array}$ & 43 & 43 & 53 & 26 & 15 & & & & & 82.284 & I \\
\hline 2 & Less awareness & 42 & 40 & 43 & 28 & 17 & 10 & & & & 79.753 & II \\
\hline 3 & Low yield & 30 & 42 & 15 & 34 & 35 & 24 & & & & 73.210 & III \\
\hline 4 & Expensive product & & & & & 28 & 34 & 28 & 36 & 54 & 29.012 & VII \\
\hline 5 & $\begin{array}{l}\text { Lack of established } \\
\text { markets }\end{array}$ & 20 & 15 & 25 & 42 & 34 & 18 & 26 & & & 67.839 & $\mathbf{V}$ \\
\hline 6 & Labour shortage & 25 & 35 & 44 & 15 & & 29 & 32 & & & 72.778 & IV \\
\hline 7 & $\begin{array}{l}\text { Lack of clarity in } \\
\text { organic policy }\end{array}$ & & & & 16 & 44 & 43 & 11 & 31 & 35 & 35.679 & VI \\
\hline 8 & High cost of inputs & & & & 19 & 7 & 22 & 50 & 56 & 26 & 25.494 & VIII \\
\hline 9 & $\begin{array}{l}\text { Lack of storage } \\
\text { facilities }\end{array}$ & 20 & 5 & & & & & 33 & 57 & 65 & 23.704 & IX \\
\hline
\end{tabular}

Majority of the organic paddy farmers perceived inadequate technology (I rank), lower yield (II rank)and less awareness (III rank)were weaknesses. 
Int.J.Curr.Microbiol.App.Sci (2019) 8(5): 427-433

Table.3 Opportunities of organic paddy farming perceived by organic paddy farmers

\begin{tabular}{|c|l|c|c|c|c|c|c|c|c|c|c|c|}
\hline S. No. & \multicolumn{1}{|c|}{ Opportunities } & \multicolumn{9}{|c|}{ Ranks } \\
\hline $\mathbf{1}$ & I & II & III & IV & V & VI & VII & VIII & IX & RBQ & Rank \\
\hline $\mathbf{2}$ & Increasing market demand & 37 & 28 & 24 & 31 & 42 & 18 & & & & 73.642 & III \\
\hline $\mathbf{3}$ & $\begin{array}{l}\text { Growing purchase power of } \\
\text { consumers }\end{array}$ & & 25 & 32 & 35 & 30 & 20 & 38 & & & 65.062 & IV \\
\hline $\mathbf{4}$ & Growing health awareness & 33 & 28 & 31 & 41 & 26 & 21 & & & & 73.951 & II \\
\hline $\mathbf{5}$ & $\begin{array}{l}\text { Growing environmental } \\
\text { concern }\end{array}$ & 32 & 24 & 36 & 45 & 28 & 5 & 10 & & & 74.815 & I \\
\hline $\mathbf{6}$ & $\begin{array}{l}\text { Premium Price } \\
\text { Sustainable use of resources }\end{array}$ & 35 & 30 & & & & & 25 & 38 & 52 & 45.185 & VI \\
\hline $\mathbf{7}$ & $\begin{array}{l}\text { Development of organic } \\
\text { paddy processing centres }\end{array}$ & & & & & & 52 & 46 & 39 & 43 & 24.012 & IX \\
\hline $\mathbf{8}$ & $\begin{array}{l}\text { Group certification Under } \\
\text { PGS }\end{array}$ & 28 & 26 & 12 & & & & 26 & 49 & 39 & 40.803 & VII \\
\hline $\mathbf{9}$ & $\begin{array}{l}\text { Periodical training on } \\
\text { organic farming at TNAU }\end{array}$ & 15 & 19 & 45 & 28 & 32 & 27 & & 14 & & 64.074 & V \\
\hline
\end{tabular}

Opportunities perceived by majority of organic paddy farmers were growing environmental concern (I rank), growing health awareness (II rank) and increasing market demand (III rank).

Table.4 Challenges of organic paddy farming perceived by organic paddy farmers

\begin{tabular}{|c|c|c|c|c|c|c|c|c|c|c|c|c|}
\hline & & \multicolumn{11}{|c|}{ Ranks } \\
\hline S. No. & Challenges & I & II & III & IV & $\mathbf{v}$ & VI & VII & VIII & IX & RBQ & Rank \\
\hline 1 & High cost of organic food & & & & & & 16 & 53 & 49 & 62 & 24.136 & VIII \\
\hline 2 & $\begin{array}{l}\text { Costly and complex organic } \\
\text { certification process }\end{array}$ & 40 & 37 & 32 & 46 & 25 & & & & & 79.074 & I \\
\hline 3 & $\begin{array}{l}\text { Most of the fields are contiguous } \\
\text { and problem of contamination }\end{array}$ & 38 & 29 & 35 & 30 & 38 & 10 & & & & 75.864 & III \\
\hline 4 & $\begin{array}{l}\text { Low awareness about organic } \\
\text { foods }\end{array}$ & & & & & & 31 & 31 & 50 & 68 & 21.420 & IX \\
\hline 5 & $\begin{array}{l}\text { Push for GMOs and Agro } \\
\text { chemicals }\end{array}$ & & & & & & 39 & 42 & 59 & 40 & 25.062 & VII \\
\hline 6 & Lack of Organic fertilizer & 25 & 10 & 15 & 62 & 48 & 20 & & & & 68.025 & $\mathbf{V}$ \\
\hline 7 & Weed problems & 42 & 34 & 28 & 17 & 59 & & & & & 76.729 & II \\
\hline 8 & Pest and disease problems & 26 & 42 & 30 & 25 & & & 35 & 22 & & 68.210 & IV \\
\hline 9 & $\begin{array}{l}\text { Maintaining organic standards and } \\
\text { certification process }\end{array}$ & 9 & 28 & 40 & & 10 & 64 & 19 & & 10 & 61.481 & VI \\
\hline
\end{tabular}

Costly and complex organic certification process (I rank), weed problems (II rank)and Most of the fields are contiguous and problem of contamination (III rank)were the challenges as perceived by organic paddy farmers. 
Fig.1 SWOC Analysis on organic paddy farming

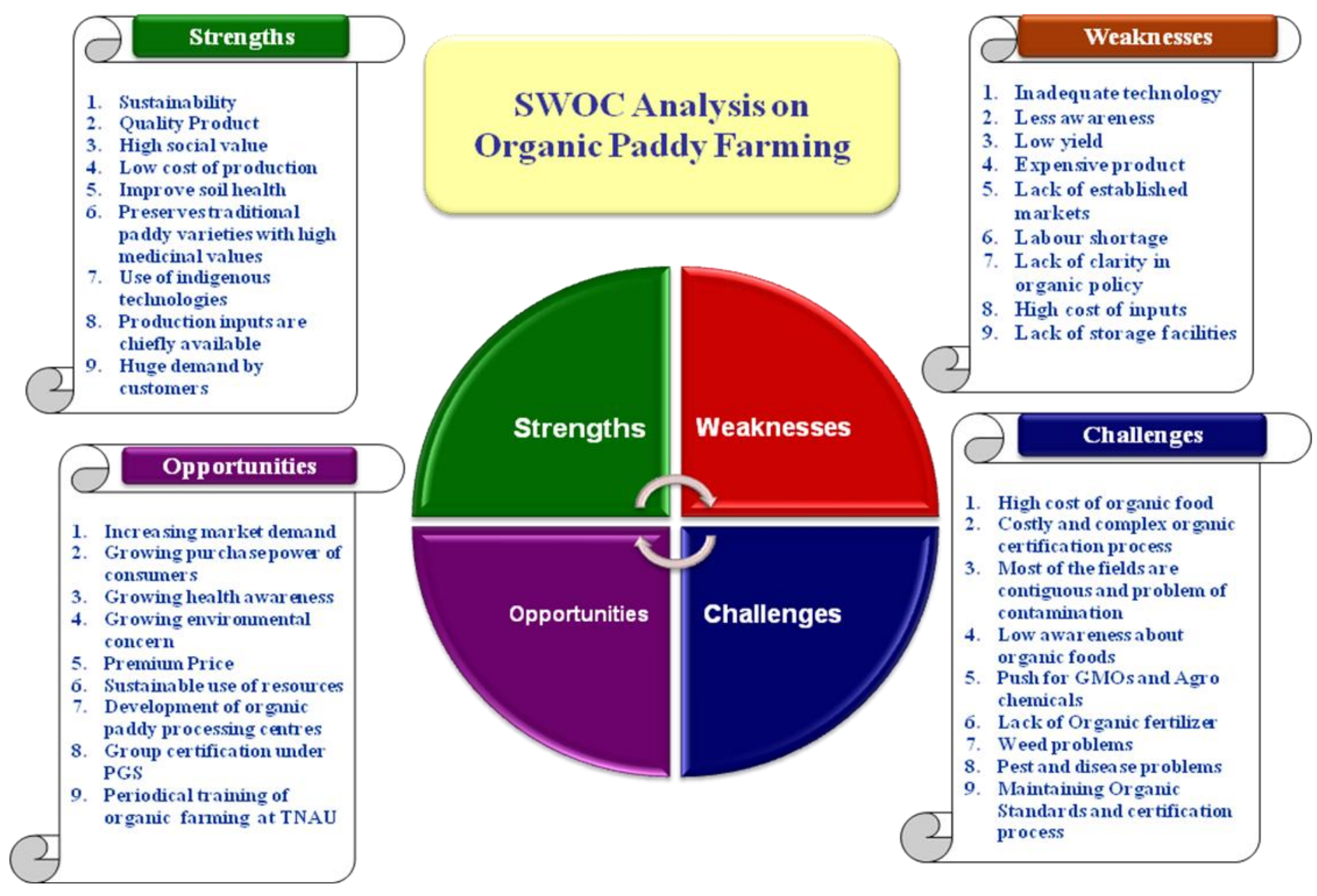




\section{Extension intervention}

More awareness programme has be conducted to empower the people on benefits of organic paddy farming there by increasing the area under organic paddy farming.

- Create the awareness about the importance of organic products.

- Provide training and method demonstration on production of organic inputs for organic paddy farming.

- Provide preseason training on organic paddy farming technologies

- Develop a model village of organic paddy farming as whole village concept.

\section{Production intervention}

- Provide production subsidy for organic paddy seed production and procure the same and sell to other organic paddy farmers with subsidised rate.

- Provide subsidy for purchase for purchase of livestock or give to organic farmers at free of cost

- Provide clear cut and simplified organic farming policy

- Reduce the cost of organic certification

\section{Processing intervention}

- Develop organic paddy processing centres at block level

- Provide hands-on training on processing and value addition in organic paddy

- Supply of organic paddy processing machineries at subsidised rate.

- Provide training cum demonstration on maintenance of processing machineries of organic paddy.

\section{Marketing intervention}

The following market interventions may be carried out to overcome the weaknesses and challenges faced by the organic paddy farming.

- Establish separate market outlet for organic paddy and its by products.

- Establish separate warehouse for storage of organic paddy

- Marketing system has to be regulated and strengthened much to the benefit of the organic paddy farmers.

In conclusion, low cost of production, sustainability and use of indigenous technologies were strengths. Inadequate technology, lower yield and less awareness were weaknesses. Opportunities were growing environmental concern, growing health awareness and increasing market demand. Costly and complex organic certification process, weed problems and most of the fields are contiguous and problem of contamination were the challenges as perceived by organic paddy farmers. Based on the result of SWOC, to overcome the weaknesses and face the challenges strategies to be followed such as documentation and validation of indigenous technologies, Develop a model village of organic paddy farming as whole village concept. Provide production subsidy for organic paddy seed production and procure the same and sell to other organic paddy farmers with subsidised rate, Provide hands-on training on processing and value addition in organic paddy, Establish separate market outlet for organic paddy and its byproducts etc.

\section{References}

Rao, B. M. 2016. SWOT analysis of Bt Cotton cultivation in Andhra Pradesh. 
The Andhra Agriculture Journal. 63 (1): $219-225$

Sabaratnam VE. 1998. Manual on field experience training for ARS
Scientists, National Academy of Agricultural Research and Management, Hyderabad.

\section{How to cite this article:}

Karpagam, D. and Jansirani, R. 2019. SWOC Analysis and strategies for Promotion of Organic Paddy Farming in Cauvery Delta Zone of Tamil Nadu, India. Int.J.Curr.Microbiol.App.Sci. 8(05): 427-433. doi: https://doi.org/10.20546/ijcmas.2019.805.050 